[Prepublication version. Pidgins/Creoles and African-American English. In The Handbook of Pidgins and Creoles, ed. by Silvia Kouwenberg and John Victor Singler, 512-542. Blackwell Publishers. 2008.]

\title{
PIDGINS/CREOLES AND AFRICAN AMERICAN ENGLISH
}

Arthur K. Spears

\section{Introduction}

This chapter deals with the relationship between African American English (AAE) and Atlantic creoles, including U.S. English-lexifier creoles." AAE is of interest for creole studies, and language contact studies more broadly, because it displays some features of grammar and language use associated with creoles, i.e., features that are "creolisms". It is also of interest because it has been claimed by some to have had a creole predecessor, by others merely to have been influenced by creoles and West African languages to a significantly greater extent than other American English dialects. The term "creolism" refers specifically to an AAE feature that

a. is found also in at least one, usually several, Atlantic creoles, though not necessarily in most or all of those languages

b. has a meaning and function (in the case of morphology and syntax) partially or fully mirroring that of a creole counterpart, and either

c.i. is not normally found in other English varieties, or

c.ii. is found in other English varieties and also in creoles; however, the AAE form's grammar is closer to that of creole counterparts. 
As one might expect, it cannot always be determined with certainty how well a form meets this set of criteria.

The term creolism is used as a matter of convenience. This term does not deny the possibility that such forms may be the result of parallel and independent development in AAE, as opposed to being the result of a creole source, creole influence, or influence of the West African language substrate of AAE

Thus, the use of creolism in this chapter indicates form/meaning parallels, not necessarily claims of creole sources specifically. Classification through this use of the term is seen as a useful first step. Hopefully, as we learn more about these items, we will be in a better position to distinguish between creolisms which do and those which do not have a creole source.

In the remaining portion of this introduction, I will discuss AAE's relationship to English-lexifier creoles in the U.S. and distinguish the two main varieties of AAE classified in reference to the notion of standardness: African American Vernacular English (AAVE) (nonstandard) and African American Standard English (AASE).

\subsection{AAE and English-lexifier creoles of the U.S.}

AAE forms a continuum or cline with creoles indigenous to the U.S. I state this based on my own personal experience, which, it may be noted, agrees with that of William Stewart (p.c. cited in Holm 1983, p.314). Kautzsch \& Schneider (2000) make a corresponding but more refined observation for earlier AAVE in the state of South Carolina. They state that "the varieties of earlier AAVE in South Carolina as recorded in the ex-slave narratives 
can be accounted for by the concept of "differential creolization," the assumption that the amount of creolization to be observed in the sub-areas of the state correlates with the density of the black population proportion in the period after Emancipation" (271). They state further that "the grammar of coastal speakers is predominantly creole and that of the inland speakers is predominantly non-creole, but that of the speakers from the intermediate region, still part of the coastal plains, has turned out to be less strongly creole than would have been anticipated" (271). In other words, there is a comparatively greater thinning out of creole features going from the coastal to the intermediate area than in going from the intermediate to the inland area. (The authors do address the difficulty of making firm claims about what is and is not a creole grammatical feature.) Their work indicates that the continuum in South Carolina - which still exists - is not new. It is plausible that the continuum in other areas is not recent either; that it is not, for example, the result of language change in the twentieth century or the post-World War II period. (See the discussion of divergence in 1.2.)

There are at least two mainland English-lexifier creoles: Gullah and AfroSeminole, the latter distinguishable from Gullah grammatically (Holm 1989, p.497), though the two language varieties are certainly close. Gullah is spoken in the states of South Carolina and Georgia including the Sea Islands off their coasts, and in Florida. In the creole speech of Florida today, there also exists, in addition to Gullah, a Bahamianrelated creole variety distinguishable from Afro-Seminole and Gullah. There are pockets of Bahamian descendants in Florida, for example, whose speech falls along a creole/AAVE continuum. (This statement is based on my own observations.) Bahamians have been immigrating to Florida up until the present, and Floridians to the Bahamas. 
Research is required to determine whether the creole end of this continuum, or cline, can usefully be distinguished from Gullah (not to mention Afro-Seminole), which has historically influenced Bahamian (Holm 1983) and, perhaps, to a lesser extent been influenced by Bahamian.

\subsection{Standard and nonstandard varieties of AAE}

Two main varieties of AAE can be distinguished with reference to the notion of standardness: the nonstandard one, which, following recent literature, I will refer to as African American Vernacular English (AAVE), and African American Standard English (AASE). Although standards are commonly considered as attaching to regional groups among others, they are not usually associated with specific ethnic or racial groups, e.g., African Americans. The term AASE implies that in the case of African Americans there is an ethnic standard variety that satisfies the conditions for standardness and also has distinctive grammatical traits associated with this ethnic group's variety.

In general, the conditions for standard status are essentially negative: a standard variety does not have certain grammatical features considered nonstandard, e.g., multiple negatives; ain't use; and double modals, as in (1).

(1) We might could do that.

'Maybe we could do that.'

Observe, however, that there is no universally recognized set of features that make up the list of nonstandard features. Distinctively African American grammatical features 
occurring in AASE are not discussed in pedagogical and prescriptive grammars, and so fall beneath the radar of those who might want to label them as nonstandard due to their being distinctively African American and the low prestige often attached to recognizably African American speech. An example of such a feature is stressed BIN (often written with capital letters in the literature to distinguish it), as in (2)

a. AASE

He's BIN gone.

b. AAVE

He BIN gone.

'He has been gone for a long time and is still gone.'

Stressed BIN, as other distinctively African American grammatical features, is highly camouflaged (Spears 1982, 1990). If features are camouflaged, speakers of nonAfrican American varieties ordinarily do not recognize that the utterances have meanings different from those of utterances in non-African American dialects for which they might be mistaken. Thus, BIN in AAE is camouflaged with respect to non-AAE dialects and is mistaken for the past participle of 'be' that occurs in all English dialects. The existence of camouflaged forms such as BIN results from (1) general societal pressures on African Americans to assimilate, pressures that are the byproduct of the subordinate position of African Americans in American society, and (2) the continuing high level of racial segregation, which was ameliorated but not eliminated in the wake of the Civil Rights Movement of the 1960s and 1970s. 
Some speakers who typically use AASE also use AAVE features, whereas some never do, except self-consciously for some metacommunicative purpose. Thus, the two forms of AAE exist separately, though some speakers deploy both varieties.

There are regional varieties of $\mathrm{AAE}$, in addition to those that are classified with respect to standardness. The regional varieties have been little discussed (see, however, Butters 1989; Wolfram \& Thomas 2002). In addition, there are African American diaspora varieties in Liberia (Singler 1984, 1989, 1991a, 1991b, 1998; Poplack 2000b; Poplack \& Tagliamonte 2001), Nova Scotia (Poplack \& Tagliamonte 2001), and the Samaná peninsula of the Dominican Republic (Debose 1983, 1988, 1994; Poplack \& Tagliamonte 2001). The different contemporary varieties have been used principally in evaluating the divergence hypothesis (especially Butters 1989) (see Section 4 below). Diaspora varieties have been examined in reference to the history of AAE, in relation to arguments against the creolist hypothesis and in favor of the neo-Anglicist hypothesis (Poplack 2000b; Poplack \& Tagliamonte 2001) and against the claims that a number of contemporary AAE features reflect divergence between black and white dialects (Singler 1998).

To be mentioned also are historical corpora that give some indication of what earlier forms of AAE may have been like. Among the corpora that have been used, Weldon (2005) lists the Works Project Administration (WPA) ex-slave narratives in Mississippi and Virginia (Rawick 1977, 1979; Perdue, Barden, \& Phillips 1976), the exslave recordings (Bailey, Maynor, \& Cukor-Avila 1991), Hyatt's hoodoo interviews (Hyatt 1970-1978), and collections of letters written by African Americans during the nineteenth century, used by Kautzsch 2002 (Wiley 1980; Miller 1978; Berlin, Reidy, \& 
Rowland 1982; Berlin et al. 1985, 1990, 1993). It should be noted, however, that the reliability of these corpora has been the subject of significant questioning (e.g., Bailey et al. 1991; Montgomery, Fuller, \& DeMarse 1993; Montgomery \& Fuller 1996; Poplack 2000a; Rickford 1999; Singler 1998; Wolfram \& Thomas 2002). Singler (1998) makes the point that features important for formulating hypotheses on earlier AAE may be absent from corpora of earlier AAE and those of diaspora varieties due purely to chance. He notes a colleague's experience of recording an important form in a sociolinguistic interview just before the tape recorder was turned off.

The plan of the remainder of this chapter is as follows. First, in Section 2 I will review features that I term creolisms. Some of the items treated below either cannot be unambiguously established as creolisms or are most likely not such. Whether the jury is still out or in with a negative verdict, they have been discussed as possible candidates for that status and, so, are covered here. Then in Section 3, I will present remarks on some affinities found in communicative practices. In Section 4, I will present a more detailed discussion of hypotheses on the genesis and evolution of AAE and an evaluation of current hypotheses in view of the discussion of grammar in Section 2. I will end with conclusions, discussing the broader implications of the foregoing discussions and their implications for future research.

Many of the examples and much of the information below are from published sources; however, I have also used my native speaker knowledge of AAE in providing examples and information. In general I will use the term AAE unless a particular point or discussion concerns AAVE or AASE alone. 


\section{Creolisms}

Creolisms in AAE morphology and syntax range from relatively clear cases, appearing fully to mirror the meaning and function of a creole counterpart (e.g., the disapproval form come and the associative plural (th)em), to those that do not clearly do so, under the definition in this writing, but whose origin and/or development may have been influenced by one or more creole grammatical features (e.g., AAE stressed BIN). Some of the grammatical features discussed in this section do not seem to be creolisms as far as we can tell, but they frequently figure in discussions of the AAE/creole relationship. In the case of such a form, it is important to state the reason for its dubious status as a creolism.

I will not be concerned with lexical similarities between English-lexifier (and also other) creoles and AAE. Such similarities are due, arguably, to a number of factors: (1) a common source in seventeenth and eighteenth century regional dialects of the British Isles, (e.g., North Country, Ireland, as well as Scotland); (2) a common source in the pidginized English in use in West Africa, especially during the latter part of the slave trade (Holm, 1991, p. 245); (3) transference from shared West African substrate languages, e.g., lexical borrowing and calques or loan translations, especially for the expression of metaphors, idioms and proverbs; (4) the direct influence of Caribbean English creoles on the development of AAE as a result of the importation of slaves from the British West Indies into the United States; and (5) more recent AAE-Creole interchanges, in both directions. Such recent contact includes, for example, the borrowing into AAE of terms connected to Jamaican reggae and dancehall music and the culture 
associated with it and the borrowing into creole languages of terms associated with hiphop music and its associated culture from the U.S.

Although lexical creolisms are significant, it must be kept in mind that lexical borrowing does not require the more extensive language contact normally required for the borrowing of grammatical features. For this reason, creolisms involving phonology, morphology, and/or syntax/semantics are more telling with respect to the genesis and development of language varieties. In the present chapter, I will not treat phonology. The decision is to some extent arbitrary, but it should be noted that on the whole the aspects of AAE grammar that have been most discussed with respect to its creole affinities come from morphology and syntax/semantics. These will be the focus of this chapter.

\subsection{Inflectional morphology}

Creoles tend to eliminate inflections and certain types of copulas altogether. Thus, English-lexifier creoles do not have main verb inflections for tense or, more specifically, an inflectionally marked past category of the verb (Winford, 1998, p.116), although some other creoles do, e.g., Louisiana French Creole. However, AAVE shows a simple past verb form despite the absence of past inflection in some cases, e.g., as a result of $[\mathrm{t}] /[\mathrm{d}]$ deletion.

There is no verb form corresponding to the English simple present in Englishlexifier creole TMA systems either, although such a form can be postulated for AAVE (and of course AASE). The AAVE verbal system is clearly not aspect-dominant, or more 
aspect- than tense-oriented, as some claim creole systems to be. Overall, the AAE TMA system is "not at all creole-like" (Winford, 1998, p.116).

Third singular $-s$ and possessive $-s$, features of AAVE, occur with low frequency. Their variable absence is exemplified in the following examples:

(3) He like(s) the blue one.

(4) She took Mark('s) book.

The absence of plural marking on nouns, e.g., two cup of sugar, does occur in contemporary AAVE, but it is quite limited in frequency and restricted essentially to nouns of weight and measure. Plural marking in Early AAE (i.e. as instantiated in the historical corpora listed above), however, was more often absent than is true today. Poplack, Tagliamonte, \& Eze (2000) argue that this fact is not indicative of a convergence toward standard English of AAE from an earlier more creole-like AAE. Using Nigerian Pidgin English (NPE) as representative of English-based Atlantic creoles, they argue instead that the conditioning factors for the absence of plural marking in Early $\mathrm{AAE}$ are quite different from those found for creoles:

Early AAE shows a robust phonological effect, NPE has none. Early AAE shows a local disambiguation effect, with more morphological marking in contexts that are number-neutral, while NPE shows the opposite, with more plural marking in contexts that are number-transparent . . Generic 
reference, or zero determiner, contributes the lowest probability of zero marking in the Early AAE varieties in which it was selected as significant, the highest in NPE" (Poplack et al. 2000, pp.96-97).

(Note that Poplack et al. treat all nouns with zero determiner as generics; the discussion of bare nouns in 2.4.2 below shows that this equivalency does not hold in AAE.)

The relevance of NPE data, especially that used by Poplack et al. (2000), is not at all certain. Poplack et al. do not identify the source of their data, except to refer the reader to Tagliamonte, Poplack, \& Eze (1997). There one learns that the source was "12 NPE speakers currently residing in Ottawa, Canada" (p.106). The eleven adults among the twelve are identified as "highly educated," several of whom were "employed as teachers or in other professional capacities before emigrating" to Canada (107). Thus, the speakers in question were "maximally likely to have been heavily influenced by some form of Standard English" (Nicholas Faraclas, p.c.).

Further, the term "Nigerian Pidgin English" encompasses both an L1 variety (a creole) and an L2 variety (a pidgin), but neither Poplack et al. (2000) nor Tagliamonte et al. (1997) presents any evidence with regard to the status of their speakers in this regard.

Given the use of "NPE" data gathered in Canada from highly educated professionals resident there, and absent information on their language histories (including, crucially, the history of their acquisition and use of NPE), Poplack et al.'s remarks on NPE cannot influence the debate on plural marking in AAE. (There are also 
issues, which I will not discuss here, as to whether, for an AAE/creole comparison, any variety of NPE would make an appropriate choice.)

Thus, while AAVE can be said to have less inflectional morphology than standard English dialects, it is not clear whether it is close enough to or distant enough from creoles in this regard to make any interesting points concerning possible creole antecedents. This is particularly so given the existence of non-African-influenced English vernaculars, e.g., in the British Isles, which also lack some of the inflectional morphology of standard Englishes (Poplack 2000b).

\subsection{Tense-Aspect Marking}

\subsubsection{Auxiliary done}

Done occurs in AAVE in sentences such as the following:

(5) I done forgot my coat.

'I have forgotten my coat.'

This form behaves largely as it does in Southern White Vernacular English, and it would appear that English dialects played the key role in its presence in AAVE. Done in creoles always has the sense of already. As example (5) shows, this is not so in AAVE (see also Edwards 2001). Nor is it so in SWVE (Feagin 1979). Edwards (2001, p.425) states that AAVE done largely has the same meaning as done in other American dialects; the exception is its contextual use as a marker of disapproval or "agitation" (see also Spears 
1990). Additionally, see Dayton (1996, pp.978ff), who lists a number of differences between done and have, but does not consider disapproval or "agitation."

Winford (1998, p.138) concludes that "it seems clear that the source of AAVE and SWVE done lies in ... certain settler dialects in the American south." Nevertheless, he states that "[ $[$ ] he semantics of done, ... particularly the sense of 'already', suggests some degree of creole semantic transfer" (emphasis in the original). According to him, the 'already' sense of done is more prevalent in South Carolina and Georgia, areas of the US where there has been historically a stronger creole influence than other areas where the 'already' sense of done is weaker (Winford 1998, p.138).

\subsubsection{Habitual be}

Habitual be is not found in any Caribbean creole (Winford, 1998, p.117). It occurs in AAVE sentences such as (6-8).

(6) She always be cookin.

'She cooks habitually.'

(7) Why you be lookin at me like that?

'Why do you habitually look at me like that.'

(8) He be in there talkin away.

'He's habitually in there talking incessantly.' 
This form has been much discussed as having Hiberno English as a possible source. Winford, in the most recent and trenchant examination of this form, however, concludes that the "most feasible conclusion is that Hiberno English was not the source of habitual be in AAVE" (Winford 1998, p.122). He argues that "the semantics of be stems from a type of substratum influence... The source of this substratum influence was creole does $b e$, which is habitual in aspect" (p.123). Rickford (1977, p.210) provides a scenario by which the phonological reduction of does in creole does be is ultimately total, leaving be by itself as an invariant form. Winford takes the position that $b e$ 's "development was due in part to substrate influence from creole varieties of English which had a semantic opposition between habitual and punctual [i.e., nonhabitual] in copula constructions quite similar to that which emerged in urban AAVE” (Winford 1998, p 126). As Rickford (1977) and Winford (1998) suggest, the hypothesis that be's source is in a creole substrate has some merit.

\subsubsection{Double auxiliary be done}

Three be done's occur in AAVE and must be distinguished (Spears 1985, 1990). They do not occur in creoles with these meanings. (See also the discussion in Dayton 1996.)

a. habitual be + done, a habitual perfect.

(9) $\quad \ldots$ and they buttons be done fell off ... 
'... and their buttons had fallen off. .' (i.e., 'it was habitually the case that their buttons had fallen off. .') (Spears 1990, p.40)

b. future perfect

(10) He be done left before you get here.

'He'll have left before you get here', i.e., 'It is the case that he leaves before you get here' or 'It will be the case that he has left before you get here.'

c. rapid reaction be done (my term; see Baugh 1983; Spears 1985, 1990).

(11) I be done whip his butt if he do that again.

'If he does that again, I'll whip his butt so fast!'

(12) If I see a ghost I be done jump out that window!

'If I see a ghost, I'll jump out of that window so fast!'

The event of the be done clause occurs after the event of the if clause in rapid reaction instances like those in (11) and (12). In contrast, the event of the be done clause occurs prior to the event of the if clause in future perfect uses like that in (10).

In regard to creoles, all that we might say is that the first two types, with habitual interpretations, may be relatable to creoles to the extent that habitual be is. 


\subsubsection{Stressed remote perfect $B I N$}

"Stressed" BIN (often capitalized in the literature to emphasize that it is stressed) is exemplified in the following examples:

(13) I BIN had this shirt.

'I've had this shirt a long time.'/'I had had this shirt a long time.'

(14) She BIN married.

'She has/had been married a long time and still is/was married.'

(15) He BIN paid that one.

'He paid that one a long time ago.'

Spears (2004) has noted that the pronunciation of $B I N$ does not always display greater volume than the items surrounding it in the clause in which it occurs. Rather, what is distinctive about $B I N$ is that it always has a relatively high pitch.

Notice that, as in the glosses for (13)-(15), this form can take either a present remote perfect or past remote perfect interpretation. In other words, it marks relative tense but not absolute tense. Thus, it may occur in a sentence expressing a future remote perfect like (16):

(16) Yeah, they gon BIN lef by the time you get there.

'Yes, they will have left way before you get here.' / 'Yes, they will have been gone a long time by the time you get there.' 
Winford (1998, p.126) states:

As I argued elsewhere. . . [Winford, 1993, p.345], the semantics of BEEN can perhaps best be explained as the result of partial reanalysis of continuative perfect been under the influence of an earlier creole past marker bin. In other words, it represents a type of partial semantic shift, with transfer (retention) of semantic features from the creole past category and incorporation of features of continuative been.

However, note that not all occurrences of BIN involve continuatives (namely, progressives). Thus, (15) above is remote perfect with no progressiveness involved. Thus, Winford's claim does not take into account with full accuracy the semantics of $B I N$.

Given that Winford (1998) does not consider unstressed been (see below) as a form occurring in AAVE, even though it in fact does occur, his conclusion requires qualification. While stressed BIN might have developed under the influence of an earlier creole "past" unstressed bin, it could also have developed under the influence of the AAVE unstressed form or under the influence of both, creole and AAVE. Moreover, unstressed been in AAVE may have developed independent of any creole substrate (or precursor) influence: independent, parallel development is conceivable.

If stressed $B I N$ is viewed in the context of unstressed been, it would be reasonable to hypothesize that it is the result of stress being placed on unstressed been, in 
conjunction with a concomitant semantic shift. Stressing for emphasis of various types is seen in other places in AAE grammar in addition to stressed BIN. Compare the use of stressed $S T A Y$ and stressed $B A C K$ in the following examples:

(17) She STAY pregnant.

'She is frequently pregnant.'

(18) He was sleepin / studyin / runnin BACK.

'He was sleepin / studyin / runnin intensely.'

This kind of stressing does not occur in creoles. Consequently, the emergence of stressed $B I N$ in AAE may be entirely independent of creoles.

\subsubsection{Unstressed been}

This been does not carry stress and is used in contexts in which other American dialects would use a past or pluperfect verb form. Instances of unstressed been, the TMA marking auxiliary counterpart to creole forms, must be distinguished from been occurring in AAVE sentences in which a preceding have has been deleted. In the corresponding standard English sentences, been is preceded by a form of the auxiliary have:

(19) She been sittin there since this morning.

'She's been sitting there since this morning.' 
(20) He been in there all day.

'He's been in there all day.'

Been in the foregoing sentences expresses continuous (progressive or non-progressive, following Comrie 1976) perfectness. Relevant examples of unstressed been are the following:

(21) But everybody thought she been had that house for years.

'But everybody thought that she had had that house for years.'

(22) He been lef.

'He had left.'

(23) Somebody been broke the window.

'Somebody broke the window.'

The sentence in (22) was overheard and was clearly pluperfect in that instance.

Winford (1998, p.127) mentions the claim (which he does not accept) that "unstressed been can ... appear in AAVE with uninflected statives and inflected nonstatives, as in the following examples from Fasold (1981, p.173).”

(24) I been know your name.

'I knew your name (before/already).'

(25) You won't get your dues that you been paid.

'You won't get your dues that you('ve [already]) paid.' 
'You won't get your dues that you paid (before).'

Winford also notes that Rickford (1974) attested such uses among speakers "in contact with Gullah, and [that such uses] may be due to interference from [Gullah]" (p.127). Going further, he states that Mufwene's examples, given in (26) and (27), “appear to be Gullah sentences and are not accepted by my AAVE informants" (p.127).

(26) Larry been gone when I come. (Mufwene 1994, p.19)

(27) I been sleeping when you come. (Mufwene 1994, p.19)

However, Winford does not consider instances of the type been lef, with unstressed been functioning as a pluperfect, as in (21).) I have heard examples such as those in (21-27) in several American cities, uttered by AAVE speakers. This form can be used in AAVE as a simple past (with be or with active verbs, as in (23)) and as a past perfect, as in (22). Clearly, unstressed been occurs in at least some varieties of AAVE in addition to Gullah and other creoles. This been's grammar is quite like creole been's grammar in that:

a. it occurs in stative (example 21) and nonstative predicates, and

b. according to context it can express past or pluperfect.

Thus, it represents a clear case of an AAVE form found also across English-lexifier creoles (whether as been, wen, or some other form comparable in meaning and function). 


\subsection{Other Elements of the Verb Phrase}

\subsubsection{Variable copula absence}

In considering copula absence, I will follow Labov (1969) and use the term copula not only for true copulas, but also for the use of be as an auxiliary. Copula absence in AAVE is confined to the present tense and does not affect first person singular, I'm being virtually categorical. This treatment of $1 \mathrm{~s}$ forms is unlike creole varieties and diasporic varieties of AAVE (Samaná English and Liberian Settler English), all of which permit copula absence with $1 \mathrm{~s}$ subjects.

Walker (2000, p.67) points out that a few nonstandard varieties of English other than AAVE display copula absence; these occur in locales such as Alabama (Feagin 1979), Mississippi (Wolfram 1974) and Yorkshire (Tagliamonte, p.c. to Walker). In his view, "the fact that ... [copula absence] has not become so highly developed there as it has in AAVE makes zero copula another spectacular and relatively recent innovation in AAVE" (67). Thus, he appears to assume extended patterning of copula absence to be a recent innovation.

Most studies (six out of nine of those reviewed in Rickford 1998 [p.190]) of the AAVE copula) have shown that the rate of absence depends on the syntactic category of the element that follows the copula. The pattern, reflecting least frequent copula absence to most frequent, is given in (28):

$$
\mathrm{NP}<\operatorname{Loc}<\operatorname{Adj}<\mathrm{V}+\text { ing }<\text { gon }
$$


Thus, the copula is absent least often in copular environments preceding an NP, and it is absent most often preceding gon. There are discrepancies in this pattern between the AAVE pattern and those found in creoles. However, as Bailey notes (Rickford 1998, p.191, n. 42), "it is not surprising that there should be some discrepancies among AAVE and various creoles in regard to the exact effects of the following environment." This is particularly worth stating since these varieties have had several centuries of independent development.

Rickford's conclusion is that the data suggest that copula absence relates AAVE to creoles. With respect to this grammatical feature, AAVE apparently arose through a restructuring process similar to that of the English-lexifier creoles (Rickford 1998, p.189). Winford's (1998, p.111) conclusion, largely compatible with Rickford's, is that the copula absence pattern is "best explained as the result of imperfect second language learning, with transfer from creolized or restructured varieties playing a significant role."

Wolfram \& Thomas $(2002$, p.79) review the ethnolinguistic distribution of copula absence in the U.S. It is for the most part limited to African Americans and to restricted groups of whites in Southern, rural, lowland areas where there is a heavier concentration of African Americans.. It does not occur among whites in Highland areas of the South, where there are many fewer African Amereicans, or in coastal, regional dialects such as those of Hyde County and the Outer Banks of North Carolina. Additionally, copula absence among whites is generally restricted to are and found only in regions that are largely nonrhotic (p.79). In these regions, there is no apparent lineage for copula absence from donor dialects in the British Isles. Thus, there is significant support for the position, 
according to them, that copula absence among Americans whites is due to accommodation to blacks.

Poplack (2000a), the editor of the volume in which Walker's study appears, acknowledges that variable copula absence does not have an English source "except perhaps as an additional strategy, complementary to contraction, for reducing prosodic complexity" (p.20). However, as Winford retorts, "There is no independent evidence that prosodic demands trigger 'deletion' of any other sounds in AAVE"; a reasonable explanation is offered by the notions of simplification and regularization in second language acquisition, processes widespread in the restructuring of English under contact (Winford (2003, p.25).

In sum, copula absence in AAVE much more closely resembles that occurring in creoles than that in other English dialects having copula absence. Also, among the white dialects in the American South that do show copula absence, the phenomenon strongly appears to have resulted from the influence of AAVE varieties.

\subsubsection{Complementizer say}

Say, functioning as a complementizer, is a form AAVE clearly shares with Englishlexifier creoles. It is a feature of Gullah and other creoles (see Rickford, 1977, pp.21213). It occurs in AAVE after verbs of communication, as in (29), and can be heard all

over the U.S. In addition, the form said sometimes occurs in place of say, as in (30).

(29) He told me say she left yesterday. 
'He told me that she left yesterday.'

(30) He told me said she left yesterday.

'He told me that she left yesterday.'

The inflected form said can be seen as the result of camouflage (Spears 1982), whereby forms that are conspicuously not standard English are modified to more resemble standard English forms, with little or no change in their AAE meaning or function. Sometimes a pronoun is inserted before said:

(31) He told me he said she left yesterday. 'He told me that she left yesterday.'

Sentences like (31) can be pronounced with no pause whatever before "he said", the lack of a pause indicating that he said is a more camouflaged form of said, itself a camouflaged form of say.

In addition to these uses of say in these constructions in AAVE, both and AAVE and AASE permit strings of uninflected verbs in what I term "serial verb-like constructions." As with the examples in (32-33), usually these occur in imperative constructions. (Spears 2001 provides a more extensive discussion of such forms).

(32) Rush run go leave this at Mary’s house.

(33) Come run go run take this next door. 
These constructions, including their camouflaged variants, strongly suggest the presence of serial verbs in earlier AAE — or perhaps the influence of a creole substrate or possible creole predecessor. Thus, serial verb constructions in creoles and serial verb-like constructions in AAVE point to a strong relationship between AAE, creoles, and the West African language substrate.

\subsubsection{Disapproval forms}

Disapproval forms are those which invariably mark disapproval. (In their invariant expression of disapproval, they differ from, for example, done and habitual be, which can mark disapproval according to context; see Myhill 1988, 1991.)

The semi-auxiliary verb come, one of these markers, expresses strong disapproval, or indignation (Spears 1982, 1990). As auxiliaries often do in creoles (see Rickford (1977, pp.203-204), come as a disapproval form may undergo initial-consonant deletion as well as subject pronoun deletion, as illustrated in (34), with (b) representing the surface reduction of (a).

(34) a. Yeah, I saw her yesterday. She come tryin to take my check.

b. Yeah, I saw her yesterday. $\left[{ }^{\mathrm{h}} \mathrm{m}\right]$ tryin to take my check.

'She had the audacity to try to take my check'.

Counterparts are found in Jamaican Creole, Guyanese Creole, Haitian Creole and probably also in additional creoles (see below for examples). (It is of interest that this 
grammatical feature - the use of a verb meaning 'come' to express disapproval - is also found in the West African language Bambara [Sheila Walker, p.c.].) Additional AAE examples are given in (35)-(37); in (36), the first come is the disapproval marker:

(35) He come callin me come yellin in my phone...

'He had the nerve to call me, yelling in my phone..'

(36) He come comin in here acting a damn fool.

'He had the audacity to come in here acting like a fool.'

(37) She come bein all hinkty with me.

'She had the nerve to be supercilious with me.'

No unquestionable examples of this semi-auxiliary come have been attested for other American English dialects, pace Michael Montgomery (cited in Winford 1998, p.141), or in other English dialects. Note, further, that the grammar of these forms is camouflaged to such an extent that it is quite complicated to distinguish true disapproval markers, with their distinctive grammar, from ostensible ones (see Spears 1982). Sentences that have been presented as examples are often ambiguous between the disapproval come and the motion verb come. The optimal sentences in this regard are ones where the motion verb come cannot occur. In such cases, the use of come can only signal disapproval, as in as in (38) and (39). 
(38) Don't come bein so stuck up.

'Don't be so damn conceited.'

(39) She come goin to sleep on me.

'She had the nerve to go to sleep on me.'

The second disapproval form to be considered in this group is the go of disapproval, often pronounced [g n] and [gõ] or rarely, gonna, like the reduced form of the future tense be going to. This form is very similar to come in meaning but not identical (Spears 1990). Counterparts have been observed in Guyanese, Jamaican, and St. Kittitian (see examples below) and are probably found more generally in the Atlantic creoles. (40) provides an AAE example of this use of $g o$.

(40) And then he go shut the window.

'And then he had the audacity to shut the window.'

These two disapproval forms combine into go come, as in (41):

(41) He go come telling me I had to change all the pipes.

'He had the audacity to tell me I had to change all the pipes.'

The disapproval of go come together has been observed in Guyanese; it most likely occurs in other creoles. 
Examples of the use of disapproval forms in creoles include the following (disapproval forms bold faced):

(42) Guyanese Creole English

Hi a kom tel mi wa fi du.

3s IMP come tell 1s what for do

'He has the nerve to tell me what to do.' (Anantram Deopersaud, p.c.)

(43) Guyanese Creole English

Hi go kom ple baas pan mi.

$3 \mathrm{~s}$ go come play boss on $1 \mathrm{~s}$

'He had the nerve to try to boss me around.' (Anantram Deopersaud, p.c.)

(44) Jamaican

Di gyal kom kom kaal mi fuul the girl come come call $1 \mathrm{~s}$ fool

'The girl had the nerve to come calling me a fool.' (The first of the two occurrences of kom is the disapproval marker; Pauline Christie, p.c.)

(45) Sranan

A gwe go lasi mi moni.

$3 \mathrm{~s}$ go-away go lost $1 \mathrm{~s}$ money.

'He left and had the nerve to lose my money.' (Mervyn Alleyne, p.c.)

(46) Haitian Créole

$\mathrm{Ou}$ pa g anyen pou ou vin montre $\mathrm{m}$.

$2 \mathrm{~S}$ NEG have nothing for $2 \mathrm{~s}$ come show $1 \mathrm{~s}$ 
'You don't have anything to show me' [with indignation, no motion involved]

(Elisée St. Preux, p.c.)

(47) Haitian Créole

$\mathrm{Pa}$ vin di $\mathrm{m}$ anyen sou fè manje.

NEG come tell 1s nothing about make food

'Don't tell me anything about cooking' [with indignation, no motion involved]'

(Elisée St. Preux, p.c.)

Disapproval marking is certainly a creolism as well as an Africanism, traceable to a West African substratum.

\subsection{Nouns}

\subsubsection{Plural and associative (th) em}

Associative them occurs in sentences such as (48). In AAVE, the full form is and them, usually pronounced an' 'em, while in creoles it is dem.

(48) John an' 'em left this morning.

'John and his friends/family/gang/colleagues left this morning.'

Unlike in creoles, them does not usually function as a more general plural marker in nonassociative contexts in AAVE; however, there are African-Americans, born and raised in the U.S., who use plural them, pronounced nem or dem, e.g., my sister-nem 'my sisters.' 
(The speakers I have heard use this form are from Greenville, North Carolina, and the Miami metropolitan area.) Associative them is distinctive in AAE and occurs in creoles; it is thus a creolism. The same is true of them as a plural, although it appears to occur in a very restricted set of AAVE dialects. Mufwene (1998, p.73) mentions a personal communication to him from Guy Bailey stating that associative them is also used by whites in the South, speculating that this usage may reflect influence from AfricanAmerican dialects. There is no reason to believe it does not reflect the influence of AAE on white speech.

\subsubsection{Bare nouns}

Bare nouns are those that are uninflected and occur without determiners, as in (49).

\section{(49) Man crazy.}

'The man is crazy.'

Clearly, all varieties of English have bare mass nouns, as in (50):

(50) Butter is tasty.

But AAE bare nouns may also take a generic interpretation:

(51) Dog ain't got no sense. (COUNT, GENERIC)

'Dogs don't have any sense/ A dog doesn't have any sense.' 
Moreover, unlike bare nouns in other varieties of English, AAVE (but not AASE) bare nouns (count and mass) may take a definite interpretation, as in (49) and also in (52) and (53):

(52) AAVE

Dog got fleas. (COUNT, DEFINITE)

'The dog's got fleas.'

(53) AAVE

Butter you bought is good! (MASS, DEFINITE)

'The butter you bought is good!'

The subject nouns in (52) and (53) also occur - with the same meaning - with the definite article present.

The generic interpretation of bare nouns is typical of creole languages, as in this Jamaican Creole equivalent of (51):

(54) Jamaican Creole

Daag na av no sens

dog NEG have no sense

'Dogs have no sense' (Joseph Farquharson, p.c.) 
According to Holm (2000, p.214), definite bare nouns do not exist in Atlantic creoles, although they do in non-Atlantic ones, for example, Tok Pisin and Nubi. However, African Portuguese-lexifier creoles in West Africa (see relevant contributions to Baptista \& Guéron forthcoming) and Palenquero (Schwegler 2002; Schwegler \& Green, forthcoming) use bare nouns to signal definiteness. Moreover, several Atlantic creoles which have definite articles also permit bare nouns with definite readings (contributions to Baptista \& Guéron forthcoming). The following Palenquero example illustrates the range of interpretations permissible for a bare noun in that language, depending on pragmatic context.

(55) Palenquero

$$
\begin{aligned}
& \text { Pelo asé ndrumimucho } \\
& \text { dog HAB sleep much }
\end{aligned}
$$

a. 'The dog sleeps a lot.' (SINGULAR, DEFINITE)

b. 'There's a dog that sleeps a lot.' (SINGULAR, INDEFINITE)

c. 'Dogs sleep a lot.' (GENERIC)

d. 'The dogs sleep a lot.' (PLURAL, DEFINITE)

e. 'Some dogs sleeps a lot.' (PLURAL, INDEFINITE)

(Schwegler 2002)

Thus, the Palenquero bare noun may contextually be interpreted as singular (definite or indefinite) or plural (definite or indefinite) as well as generic. Consequently, certain behaviors of AAE bare nouns are like those of a few Atlantic creoles (even if not most). 


\subsection{Fossils}

One category of language item that has been ignored in studies of AAE and its status with respect to creoles is fossils. These are grammatical features that are fossilized in a set expression - due no doubt to frequent use - much as suppletive verb forms, for example, English went, have remained in the language. One example of an AAE fossil creolism is a lie, as in (56).

You/He/They a lie.

'You're/He's/They're lying.'

The structure is most frequent in the speech of children. It is not a reduced form of You're a liar. Furthermore, lie cannot be used as a noun to mean 'liar'; thus, a sentence like (57) is ungrammatical.

(57) *A lie will tell you anything.

'A liar will tell you anything.'

The $a$ in (56) can clearly be related to $(d) a$, the creole nonpunctual marker that expresses imperfective aspect with active verbs (e.g., Gullah).

\subsection{The Status of Creolisms in AAVE: Conclusion}


Attention should be drawn to certain features discussed above: those which at present are not always recognized in the AAE literature as creolisms and those which have not been treated in the literature as creolisms, or not treated in the literature at all. Unstressed been and the say/said complementizer fall into the first category. Plural them and disapproval markers fall into the second. Given the hitherto small total number of creolisms, these additions to the list are quite significant. Furthermore, it is important to keep in mind the phenomenon of camouflage (Spears 1982), whereby the distinctively creole or creole-like meanings and functions of forms are hidden because in most sentences they can be mistaken for ordinary non-AAE English words. The disapproval forms come and go are examples of this. The creolisms discussed above, in addition to fossil creolisms and camouflage, suggest that AAE may be much more creole-like than is commonly realized even among AAE scholars.

\section{Communicative Practices}

While creolisms in the grammar and lexicon of AAE are significant, a number of AAE scholars believe that it is in the area of communicative practices, or language use, that the most creolisms are to be found. The following discussion presents an overview of some of the communicative practices common to AAE and creoles.

Morgan (1993) calls attention to the use of indirect speech and the ways in which it is used in AAE and Caribbean creoles. Indirectness involves ambiguity, subtle irony, 
satire, and veiled criticism; the use of metaphors and euphemisms; the use of proverbs; and dropping remarks to be overheard by person(s) being criticized. As Morgan notes, folklorists and anthropologists have observed widespread use of indirect speech in West African societies; she sees these societies as the source of its use in African American and Caribbean speech.

Morgan speaks of counterlanguage as "a conscious attempt on the part of U.S. slaves and their descendants to represent an alternative reality through a communication system based on ambiguity, irony, and satire" (1993, p.423). She sees it as a response to the "total institution" (Goffman 1961, p.xiii) of U.S. slavery:

First, as a total institution, U.S. slavery required that slaves exhibit childlike behavior in the presence of whites. This behavior, which supported the paternalistic and humanitarian rationalizations of U.S. slavery, was reinforced through a communication style imposed on slaves which interpreted any expression of ideas, direct eye contact, or questions as potentially aggressive acts. Second, in response to this repressive and regimented communication environment, slaves developed a system of intragroup communication based on the use of ambiguity and irony in African songs and public announcements. Thus, in the case of Afro-Americans in the United States, indirect speech was an aspect of the counterlanguage because it was a shared norm among the slaves while white plantation owners and overseers had little knowledge of it (Morgan 1993, p.424). 
"Indirection" appears to have developed as a life-preserving, soul-saving, means of resistance - particularly to the workings of white supremacist racial hatred and internalized oppression during slavery and after, for example, during the Reign of Terror in the U.S. (Often euphemized by the term Jim Crow Era, it lasted from the mid-1870s to the mid-1960s.)

As noted, Morgan suggests that indirectness is a part of Caribbean as well as African American speech. However, she states:

While indirectness in the Caribbean retains many of its African characteristics, it has become a communication norm throughout society. In the United States, however, indirection has been expanded to a "way of speaking" with intragroup "norms of interpretation" (Hymes 1972) which signal both the social reality of the antisociety as well as solidarity among African descendants (427).

\section{The History of AAE Revisited}

There have been several views on the history of AAE. The Anglicists, including American dialectologists (the latter writing mostly in the decades after World War II), held that the distinctive grammatical features of AAE came from British Isles dialects of English, with which earlier blacks had come into contact. These features in some cases had disappeared from other dialects but remained in AAE. Other features characteristic of 
AAE were also found in the speech of American whites of the same region and of a similar economic background (Krapp 1924; Kurath 1949; McDavid \& McDavid 1951). This view was the linguistic counterpart of eradicationist views of black culture in general (e.g., Frazier 1939), claiming that the African heritage of African Americans had largely been obliterated due to the devastation of slavery.

The subsequently emerging creolist hypothesis, whose earliest proponents were Bailey (1965) and Stewart (1967, 1968), and which was thereafter widely disseminated by Dillard (1972), was a reaction to the Anglicist view and claimed that AAE had formerly been a creole language, much like Gullah, spoken widely throughout the plantation American South. The creole past explained AAE's grammatical distinctiveness. In the post-Emancipation period, AAE underwent decreolization in most areas, producing contemporary AAE. Gullah, in the southeastern, coastal U.S., on this view, was a remnant of an erstwhile widespread creole.

Afterwards, some scholars took a modified creolist position (e.g., Fasold 1981), concluding that the creolist view had merit, but that the stronger form supported by Stewart and Dillard lacked sufficient evidence.

A third view developed later in the mid-1980s, proposing that AAE had significantly diverged historically from other dialects of American English and that divergence played a key role in producing the distinctiveness of contemporary AAE (Ash \& Myhill 1986; Myhill \& Harris 1986; Labov 1985, 1987, 1998; Labov \& Harris 1986; Bailey 1987; Bailey \& Maynor 1987, 1989). Bailey \& Maynor (1989) present one statement of this view, which is that, first, AAVE is diverging from white dialects, especially in the South and that, second, it was previously converging for many years, but 
that convergence as the major trend had ended (Bailey \& Maynor 1989, p.13; see Spears 1992 for further details). Labov weighs in on the side of those supporting divergence, stating that

$[t]$ he general conclusion that is emerging from studies of the history of AAVE is that many important features of the modern dialect are creations of the twentieth century and not an inheritance of the nineteenth. The creole affinities of AAVE and the creole-like structural properties that we do observe are not to be accounted for by direct transmission, but by the more subtle process of substrate influence and by parallel drift or development (Labov 1998, p.119).

He recognizes that this view is open to challenge, but feels that it is the best working hypothesis available at the time (119).

In the 1990s, what has sometimes been termed the "neo-Anglicist hypothesis" emerged (Montgomery et al. 1993; Montgomery \& Fuller 1996; Poplack 2000b). Poplack describes this position as follows:

the grammatical core of contemporary AAVE developed from an English base, many of whose features have since disappeared from all but a select few varieties (African American and British-origin), whose particular sociohistorical environments have enabled them to retain reflexes of features no longer attested in Standard English ... This scenario suggests that the many grammatical distinctions between contemporary varieties of AAVE and American and British 
English are relatively recent developments [since the Civil War] ... in a social context highly propitious to racial segregation and divergence. This does not of course preclude... distinctly African and/or creole contributions to the current physiognomy of AAVE. But. . the details of the grammatical core were acquired from earlier English models (Poplack 2000a, p.1).

Several problems are found in examining this view. We would assume that by "grammatical core" Poplack means the features treated in Poplack (2000b): variable copula absence, plural marking, negation, was and were use, and relativization. However, by no stretch of the imagination could this group of features be considered the grammatical core of AAVE since it does not include the tense-aspect-mood auxiliaries unique to AAVE or other Africanisms and/or creolisms such as associative them. Moreover, as noted above, variable copula absence, as Poplack admits, does not have an English source "except perhaps as an additional strategy, complementary to contraction, for reducing prosodic complexity" (Poplack 2000a, p.20).

The most detailed critique of the divergence view is Butters (1989), whose data from a number of U.S. regions have not been adequately engaged by divergence proponents. His work refutes strong divergence claims with data from several regions where AAVE is spoken showing convergence with respect to several features presented as supporting the divergence view. Furthermore, even if divergence views are accepted on face value, they can only be accepted as arguing for divergence involving specific features in specific geographical areas, not a fundamental pattern of divergence. There are a number of reasons for not accepting the neo-Anglicist view on face value. These 
relate to the nature of the data, details of the contact situation encompassing Africans and Europeans, and the sociohistorical context of earlier African Americans (Wolfram \& Thomas 2002, p.14).

Aside from the various forms of the creolist and Anglicist hypotheses, there are also what we may call intermediate hypotheses. Winford put forward one version, proposing that, "though early BEV [Black English Vernacular, i.e., AAVE] may not have been a fully fledged creole, it arose through a process of restructuring in which a creole substrate played a significant role" (Winford 1992, p.311). Winford goes on to state that "the evidence from other studies ... points to closer similarity between early BEV and intermediate creoles like TC [Trinidadian Creole English]. Moreover, the creolist hypothesis presupposes a rate of decreolization whose speed is not matched by any other New World creole" (p.350). He then states that "[m]y own position ... is that BEV emerged as a result of relatively rapid language shift toward English dialects by speakers of an earlier creole variety similar to Gullah" [emphasis added] (p.350), and goes on to suggest that this notion of rapid shift from a creole variety toward English dialects should perhaps be kept distinct from the notion of decreolization, since "typical" cases of decreolization are comparable to cases of language maintenance rather than language shift. Thus, in this writing he sees the genesis of AAVE (i.e., BEV) in the contact between a creole with earlier settler English vernaculars, a position that makes a subtle but crucial distinction between what went into the genesis of AAVE and what emerged from that genesis as early AAVE. Under this view, early AAVE would not have been a creole as such. This hypothesis can be termed the "creole substrate hypothesis." This view is expressed also in Winford (1998), where he argues "that the earliest forms of 
AAVE were not creole-like, but second language versions of the settler dialects" (Winford 1998, p.99).

There are other scholars who take a view that appears to assign less of a role to a creole substrate, in contradistinction to Winford, yet, like him, maintain that it neither started off as a creole nor as a variety composed uniquely of features from white vernaculars of English but shows traits of both. On this view, as with Winford's, there would have been no crystallized, indigenous African American creole widespread in the South, Gullah or otherwise. This view is essentially that of Holm $(1992,2004)$ and Mufwene (2000).

Wolfram \& Thomas (2002, pp.186ff) discuss several processes that quite possibly played a role in AAVE genesis and development. Largely in line with Winford, they accept the strong possibility that the presence of creolisms in AAVE does not necessarily imply that AAVE results from the decreolization of an earlier widespread creole in the U.S. Such creolisms could very well have come from a creole substrate that figured in the genesis of AAVE, along with the role played by settler dialects. Thus, earlier creolist positions such as Stewart's $(1967,1968)$ and Dillard's (1972) make claims that are not inescapable given what we know. The genesis and development of Tristan da Cunha English (Schreier 2001) provides a documented example of this scenario, i.e. the genesis of a dialect of English with creole substrate influences. The views of Winford and Wolfram \& Thomas make a crucial distinction between language shift in the context of a creole substrate, which they find plausible, and language maintenance with decreolization, which forms the core of the creolist hypothesis. 
Wolfram \& Thomas (2002) also note the possibility of restructuring stemming from language contact (as opposed to borrowing from a substrate, as just outlined) as an explanation for the grammatical particulars of AAVE. For example, Consonant Cluster Simplification (CCS) "is most often traceable to a language contact situation involving a language that does not have syllable-coda clusters, as was the case for most West African languages spoken by African slaves ... Thus, a native speaker of one of these languages might adopt this phonological trait whether or not their learning of English involved a middle passage through a pidgin or creole" (p.186).

They also consider the possibility of independent development as a product of natural language change, i.e. after AAVE had already come into existence, which might well involve copula absence, prevocalic CCS, or $3 \mathrm{~S}-s$ absence. "However, such independent development has not been documented for long-term isolated, monolingual English situations" (Wolfram \& Thomas 2002, p.187). They note that there may have been multiple processes working in conjunction that produced the pertinent features. In sum, Wolfram \& Thomas (2002) largely agree with Winford but put more stress on language contact restructuring, while minimizing independent development.

\section{Conclusions}

The review in Section 2 of connections among grammatical features of AAE and creoles raises the question of whether a reassessment of the relationship is in order. Serious problems with the neo-Anglicist and divergence views as statements of major trends have 
been noted above. It would appear that some type of intermediate view is supportable, but what relative importance should be assigned to creole substrates, processes induced by language contact, and perhaps to a much lesser extent, independent development?

The preceding discussion presents creolisms only very recently treated in the literature, e.g. unstressed been, or not treated in the literature at all, e.g. the treatment of bare nouns. In addition there are creolisms whose existence has largely been ignored in the literature on the history of AAE, e.g. disapproval markers, associative them, and complementizer say. There are also phonological characteristics, not treated above (Bailey \& Thomas 1998, Thomas \& Bailey 1998) along with potentially new AAE-creole connections such as pitch and intonation (not treated in this chapter) (Wolfram \& Thomas 2002, Chapter 8), and the apparent existence of limited lexical tone (Spears 2004). Taken together, these do strengthen the case for resurrecting a creolist hypothesis, even one positing decreolization in at least some AAE varieties; certainly, the sum of the data presented in Section 2 point to a qualitatively closer relationship between AAE and creoles, not merely a quantitatively closer one. However, there is an important distinction to consider in dealing with these shared grammatical features, or creolisms, concerning what they reveal in regard to subsystems of the overall grammar of these languages, e.g., pronominal and tense/aspect/mood subsystems, etc. Labov (1998) has argued for a “coexistent" system of African-American tense-aspect-mood auxiliaries, concluding that the elements in this system point to both divergence and convergence historically within the realm of American dialects. In contrast, Green (2002) treats these same auxiliaries as integral to the overall AAE auxiliary system. Nevertheless, regardless of how the group of auxiliaries is treated in AAE grammar, the fact remains that most of the individual 
items have no counterparts in creole grammars and the auxiliary system as a whole does not remotely mirror that of any creole (Winford 1992).

Also, in the final analysis, while these observations make any neo-Anglicist hypothesis such as Poplack's unsustainable, they are, strictly speaking, compatible with the intermediate hypotheses. The forms singled out above as having been ignored or largely so in AAE history discussions, taken as individual items or as elements in grammatical subsystems, do not argue straightforwardly for a new take on AAE history.

Nevertheless, it should be kept in mind that the key reasons that AAE is not assumed to have had a creole past is that we have no record of a full-fledged, indigenous, English-lexifier creole in the U.S that was widespread, beyond the pockets in which Gullah and Afro-Seminole are spoken. We, as creolists and AAE scholars, are, however, left with an important question: At what point does the accumulation of creolisms begin to suggest that at least some strands of AAE may well once have been creole, having subsequently decreolized into the forms of AAE we know today?

Two of the key criteria for creole language status have been a creole-like verbal and pronominal subsystems, neither of which any variety of AAE has. However, the existence of camouflage and other factors suggests interesting possibilities for formulating new hypotheses on AAE origins.

In connection with such hypotheses, note in addition to the observations just made, that, since creole-like pronominal or verbal systems would be highly conspicuous as divergent from other dialects of American English, one might argue that these systems, as other highly conspicuous creole features — ones that cannot be adequately camouflaged - have been suppressed, particularly as the African American population 
received more formal education and had more meaningful contact with whites in more egalitarian situations. Clearly, African Americans have historically had more access to education and economic advancement longer than their creole-speaking counterparts in other areas of the Americas. Also, African Americans have been minority populations in almost all areas of the U.S., always under the gaze of the majority, dominant white population and the conforming pressures that the latter could not help but impose. Thus, language accommodationist pressures have had more contexts in which to impact on the language of African Americans than they have had to do so on the creole-speaking populations outside of the U.S. Nevertheless, the corollary of feature camouflage is that it enables creole feature retention as a function of the camouflaged feature's low salience to the dominant white population. Such features may take on status as badges of ethnicity (see for example Wolfram \& Thomas 2002; Wolfram forthcoming).

Note too that overall very little intensive grammar-oriented research has been carried out on $\mathrm{AAE}$, despite the mountains of research on $\mathrm{AAE}$ in variationist and other veins. This has left us with a great deal of knowledge about very few grammatical features of AAE, while global descriptive studies of AAE varieties have for the most part remained unattempted (see, however, Green 2002). It is extremely telling that critical important grammatical features like unstressed been and bare nouns with definite reference, features that relate $\mathrm{AAE}$ to creoles, are only now being added to the literature. This indicates that we have actually been on shaky ground in hypothesizing what the history of AAE may have been. Thus, new hypotheses would take into account 
- our shallow knowledge of AAE grammar, due to grammatical camouflage and the reigning paradigms under which AAE research has been conducted, among other factors;

- the special assimilationist pressures on African Americans due to the sociodemographic and economic particulars of American history;

- creolisms occurring in standard and especially in nonstandard varieties of AAE;

- the possibility of decreolization in at least some AAE varieties (witness the presence of features such as unstressed been, bare nouns, complementizer say, and various fossils); and

- a possible basilectalization scenario, with the diffusion of features from conceivable earlier, more widespread indigenous creoles (or a creole) to noncreole AAE varieties as a result of the segregationist pressures of the Reign of Terror.

\section{References}

Ash, Sharon \& John Myhill (1986) Linguistic correlates of inter-ethnic contact. In: Sankoff (ed.), pp. 33-44.

Bailey, Beryl (1965) A new perspective in American Negro dialectology. American Speech 11, 1-11.

Bailey, Guy (1987) Are black and white vernaculars diverging? Papers from the NWAV panel discussion. American Speech 62, 32-40. Bailey, Guy \& Natalie Maynor (1987) Decreolization? Language in Society 16, 449-74. 
Bailey, Guy \& Natalie Maynor (1989) The divergence controversy. American Speech 64, 12-39.

Bailey, Guy, Natalie Maynor, \& Patricia Cukor-Avila (eds.) (1991) The Emergence of Black English. John Benjamins, Amsterdam.

Bailey, Guy, \& Erik Thomas (1998) Some aspects of African-American Vernacular English phonology. In: Mufwene et al. (eds.), pp. 85-109.

Baptista, Marlyse \& Jacqueline Guéron (eds.) (forthcoming) Bare Nouns and the Structure of DP in Creole Languages. John Benjamins, Amsterdam

Baugh, John (1983) Black Street Speech: Its History, Origin, and Structure. University of Texas Press, Austin.

Berlin, Ira, Barbara J. Fields, Thavolia Glymph, Joseph R. Reidy, \& Leslie S. Rowland (eds.) (1985) Freedom: A Documentary History of Emancipation, 1861-1867, Vol. 1, series 1: The Destruction of Slavery. Cambridge University Press, Cambridge.

Berlin, Ira, Thavolia Glymph, Steven F. Miller, Joseph R. Reidy, Leslie S. Rowland, \& Julie Saville (eds.) (1990) Freedom: A Documentary History of Emancipation, 18611867, Vol. 3, series 1: The Wartime Genesis of Free Labor: The Lower South. Cambridge University Press, Cambridge.

Berlin, Ira, Steven F. Miller, Joseph R. Reidy, \& Leslie S. Rowland (eds.) (1993) Freedom: A Documentary History of Emancipation, 1861-1867, Vol. 2, series 1: The Wartime Genesis of Free Labor: The Upper South. Cambridge University Press, Cambridge. 
Berlin, Ira, Joseph R. Reidy, \& Leslie S. Rowland (eds.) (1982) Freedom: A

Documentary History of Emancipation, 1861-1867, Vol. 1, series 2: The Black Military

Experience. Cambridge University Press, Cambridge.

Butters, Ron. (1989) The Death of Black English: Divergence and Convergence in Black and White Vernaculars. Peter Lang, Frankfurt.

Comrie, Bernard (1976) Aspect: An Introduction to the Study of Verbal Aspect and

Related Problems. Cambridge University Press, Cambridge.

Dayton, Elizabeth. 1996. Grammatical Categories of the Verb in African-American

Vernacular English, Parts I \& II. Ph.D. dissertation, University of Pennsylvania.

Debose, Charles (1983) Samaná English: A dialect that time forgot. Proceedings of the

Ninth Annual Meeting of the Berkeley Linguistics Society. Berkeley, CA: Linguistics

Department, University of California, Berkeley, pp. 47-53.

Debose, Charles (1988) Be in Samaná English. (Occasional Paper 21.) Society for

Caribbean Linguistics, University of the West Indies, Mona, Jamaica.

Debose, Charles (1994) Creole English in Samaná. In: Frances Ingemann (ed.) 1994 Mid-

America Linguistic Conference Papers, vol.2. Department of Linguistics, University of

Kansas, Lawrence, pp. 341-350.

Dillard, Joey L. (1972) Black English: Its History and Usage in the United States.

Random House, New York.

Edwards, Walter F. (2001) Aspectual $d \star n$ in African Amereican Vernacular English in

Detroit. Journal of Sociolinguistics 5, 413-427.

Fasold, Ralph W. (1981) The relation between black and white speech in the South.

American Speech 56, 163-89. 
Feagin, Crawford. (1979) Variation and Change in Alabama English: A Sociolinguistic Study of the White Community. Georgetown University Press, Washington, DC.

Frazier, E. Franklin (1939) The Negro Family in the United States. University of Chicago

Press. Chicago.

Goffman, Erving. (1961) Asylums. Doubleday, Garden City, NY.

Green, Lisa J. (2002) African American English: A Linguistic Introduction. Cambridge University Press, New York.

Holm, John (1983) On the relationship of Gullah and Bahamian. American Speech 58, 303-318.

Holm, John (1989) Pidgins and Creoles. Vol. 2: Reference Survey. Cambridge University Press, Cambridge.

Holm, John (1991) The Atlantic creoles and the language of the Ex-Slave Recordings. In: Bailey et al. (eds.), pp. 231-248.

Holm, John (1992) A theoretical model for semi-creolization. Paper presented at the meeting of the Society for Caribbean Linguistics. University of the West Indies, Cave Hill, Barbados.

Holm, John (2000) An Introduction to Pidgins and Creoles. Cambridge University Press, Cambridge.

Holm, John (2004) Languages in contact: The partial restructuring of vernaculars. Cambridge University Press, Cambridge. Hyatt, Harry Middleton (1970-1978) Hoodoo-Witchcraft—Conjuration—Rootwork, vols. 1-5. The Alma Egan Hyatt Foundation, Washington, DC. 
Hymes, Dell (1972) Models of the interaction of language and social life. In: John J. Gumperz \& Dell Hymes (eds.), Directions in Sociolinguistics: The Ethnography of Communication. Holt, Rinehart and Winston, New York, pp. 35-71.

Kautzsch, Alexander (2002) The historical Evolution of Earlier African American English: An Empirical Comparison of Early Sources. Mouton de Gruyter, Berlin. Kautzsch, Alexander \& Edgar W. Schneider (2000) Differential creolization: Some evidence from Earlier African American Vernacular English in South Carolina. In: Ingrid Neumann-Holzschuh \& Edgar W. Schneider (eds.) Degrees of Restructuring in Creole Languages. John Benjamins, Amsterdam, pp. 247-274.

Krapp, George Philip (1924) The English of the Negro. American Mercury 2, 190-5. Kurath, Hans (1949) A Word Geography of the Eastern United States. University of Michigan Press, Ann Arbor.

Labov, William (1969) Contraction, deletion and inherent variability of the English copula. Language 45, 715-62.

Labov, William (1985) The increasing divergence of black and white vernaculars:

Introduction to the research reports. Unpublished manuscript, University of Pennsylvania.

Labov, William (1987) Are black and white vernaculars diverging? Papers from the NWAVE XIV panel discussion. American Speech 62, 5-12.

Labov, William (1998) Co-existent systems in African American vernacular English. In: Mufwene et al. (eds.), pp. 110-153.

Labov, William \& Wendell A. Harris (1986) De facto segregation of black and white vernaculars. In: Sankoff (ed.), pp. 1-24. 
McDavid, Raven I., Jr., \& Virginia G. McDavid (1951) The relationship of the speech of American Negroes to the speech of whites. American Speech 26, 3-17.

Miller, Randall M. (1978) “Dear Master:” Letters of a Slave Family. Cornell University Press, Ithaca, NY.

Montgomery, Michael, Janet Fuller, \& Sharon DeMarse (1993) "The black men has wives and sweet harts [and third person $-s$ ] jest like the white men": Evidence for verbal $-s$ from written documents on nineteenth-century African-American speech. Language Variation and Change 5, 335-57.

Montgomery, Michael, \& Janet Fuller (1996) Verbal $-s$ in 19th-century AfricanAmerican English. In: Edgar W. Schneider (ed.), Focus on the USA. John Benjamins, Amsterdam, pp. 211-30.

Morgan, Marcyliena (1993) The Africanness of counterlanguage among AfroAmericans. In: Salikoko S. Mufwene (ed.) Africanisms in Afro-American Language Varieties. University of Georgia Press, Athens, pp. 423-435.

Mufwene, Salikoko S. (1994) On decreolization: the case of Gullah. In: Marcyliena Morgan (ed.) Language and the Social Construction of Identity in Creole Situations.

UCLA Center for Afro-American Studies, Los Angeles, pp. 63-99.

Mufwene, Salikoko S. (1998) The structure of the noun phrase in African-American Vernacular English. In: Mufwene et al. (eds.), pp. 63-80.

Mufwene, Salikoko S., John R. Rickford, Guy Bailey, \& John Baugh (eds.) (1998)

African-American English: Structure, History and Use. Routledge, New York.

Mufwene, Salikoko S. (2000) Some sociohistorical inferences about the development of African American English. In: Poplack (ed.), pp. 233-263. 
Myhill, John, \& Wendell A. Harris (1986) The use of the verbal $-s$ inflection in Black English Vernacular. In: Sankoff (ed.), pp. 25-31.

Myhill, John (1988) The rise of be as an aspect marker in Black English Vernacular. American Speech 63, 304-25.

Myhill, John (1991) The use of invariant be with verbal predicates in BEV. In: Walter F. Edwards \& Donald Winford (eds.) Verb Phrase Patterns in Black English and Creole.

Wayne State University Press, Detroit, pp. 101-113.

Perdue, Charles L., Thomas E. Barden, \& Robert K. Phillips (1976) [1992] Weevils in the Wheat: Interviews with Virginia Ex-Slaves. University Press of Virginia, Charlottesville.

Poplack, Shana (2000a) Introduction. In: Poplack (ed.), pp. 1-32.

Poplack, Shana (ed.) (2000b) The English History of African American English. Blackwell, Malden, MA.

Poplack, Shana, \& Tagliamonte, Sali (2001) African American English in the Diaspora. Blackwell, Malden, MA.

Poplack, Shana, Sali Tagliamonte, \& Ejike Eze (2000) Reconstructing the source of Early African American English plural marking: A comparative study of English and Creole. In: Poplack (ed.), pp. 73-105.

Rawick, George (ed.) (1977/1979) The American Slave: A Composite Autobiography. Supplement. Series 1 and 2, vols. 10 and 12. Greenwood, Westport, CT.

Rickford, John R. (1974) The insights of the mesolect. In: David DeCamp \& Ian F. Hancock (eds.) Pidgins and Creoles: Current Trends and Prospects. Georgetown University Press, Washington, DC, pp. 92-117. 
Rickford, John R. (1977) On the question of prior creolization in Black English. In:

Albert Valdman (ed.) Pidgin and Creole Linguistics. Indiana University Press,

Bloomington, pp. 199-221.

Rickford, John R. (1998) The creole origins of African-American Vernacular English:

Evidence from copula absence. In: Mufwene et al. (eds.), pp. 154-200.

Rickford, John R. (1999) African American Vernacular English. Blackwell, Malden, MA.

Sankoff, David (ed.) 1986 Diversity and Diachrony. John Benjamins, Amsterdam.

Schreier, Daniel M. (2001) Nonstandard Grammar and Geographic Isolation: The

Genesis, Structure, and Development of Tristan da Cunha English. Ph.D. dissertation, University of Fribourg.

Schwegler, Armin. 2002. Reconsidering the evidence: bare nouns in Palenquero and what they really mean. Paper presented at the Society for Pidgin and Creole Linguistics meeting, San Francisco, CA.

Schwegler, Armin, \& Katherine Green (forthcoming) Palenquero (Creole Spanish). In:

John Holm \& Peter Patrick (eds.) Comparative Creole Syntax. Battlebridge Publications, London.

Singler, John Victor (1984) Variation in Tense-Aspect-Modality in Liberian English.

Ph.D. dissertation, University of California, Los Angeles.

Singler, John Victor (1989) Plural marking in Liberian Settler English. American Speech 64, 40-64. 
Singler, John Victor (1991a) Copula variation in Liberian Settler English and American Black English. In: Walter F. Edwards \& Donald Winford (eds.) Verb Phrase Patterns in Black English and Creole. Wayne State University Press. Detroit, pp. 129-164.

Singler, John Victor (1991b) Liberian Settler English and the Ex-Slave Recordings: A comparative study. In: Bailey et al. (eds.), pp. 249-274.

Singler, John Victor (1998) What's not new in AAVE. American Speech 73, 227-56.

Spears, Arthur K. (1982) The Black English semi-auxiliary come. Language 58, 850-72.

Spears, Arthur K. (1985) Review of John Baugh, Black Street Speech: Its History,

Origin, and Structure. Language in Society 14, 101-108.

Spears, Arthur K. (1990) The grammaticalization of disapproval in Black American

English. In: Robert Rieber (ed.) CUNYForum: Papers in Linguistics, No. 15.1 \& 2. The Linguistics Department, the CUNY Graduate Center, New York, pp. 30-44.

Spears, Arthur K. (1992) Reassessing the status of Black English (Review article). Language in Society 21, 675-82.

Spears, Arthur K. (2001) Serial verb-like constructions in African-American English.

Paper presented at the meeting of the Society for Pidgin and Creole Linguistics. Washington, DC.

Spears, Arthur K. (2004) The question of tone in African American English. Paper presented at the joint conference of the Society for Caribbean Linguistics, Society for Pidgin and Creole Linguistics, and Asociación de Criollos de Base Lexical Portuguesa e Española, Curaçao, Netherlands Antilles.

Stewart, William A. (1967) Sociolinguistic factors in the history of American Negro dialects. The Florida FL Reporter 5.2, 11, 22, 24, 26. 
Stewart, William A. (1968) Continuity and change in American Negro dialects. The Florida FL Reporter 6, 3-4, 14-16, 18.

Tagliamonte, Sali, Shana Poplack \& Ejike Eze (1997) Plural marking patterns in Nigerian Pidgin English. Journal of Pidgin and Creole Languages 11, 103-129.

Thomas, Erik, \& Guy Bailey (1998) Parallels between vowel subsystems of African American Vernacular English and Caribbean Anglophone Creoles. Journal of Pidgin and Creole Linguistics, 2, 267-296.

Walker, James A. (2000) Rephrasing the copula: Contraction and zero in Early African American English. . In: Poplack (ed.), pp. 35-72.

Weldon, Tracey L. (2005) Review article of Walt Wolfram \& Erik Thomas, The Development of African American English, and Alexander Kautzsch, The Historical Evolution of Earlier African American English: an Empirical Comparison of Early Sources. Language 81, 478-494.

Wiley, Bell (1980) Slaves No More. Letters from Liberia 1833-1869. The University Press of Kentucky, Lexington.

Winford, Donald (1992) Back to the past: the BEV/creole connection revisited. Language Variation and Change 4, 311-357.

Winford, Donald (1993) Predication in Caribbean English Creoles. John Benjamins, Amsterdam.

Winford, Donald (1998) On the origins of African American Vernacular English—a creolist perspective. Part II: Linguistic features. Diachronica 15, 99-154.

Winford, Donald (2003) Ideologies of language and socially realistic linguistics. In: Sinfree Makoni, Geneva Smitherman, Arnetha F. Ball, \& Arthur K. Spears (eds.) Black 
Linguistics: Language, Society, and Politics in Africa and the Americas. Routledge, London, pp. 21-39.

Wolfram, Walt (1974) The relationship of Southern White speech to Vernacular Black English. Language 50, 498-527.

Wolfram, Walt (forthcoming) The supraregional development of African American Vernacular English. In: Arthur K. Spears (ed.) Black Language in the English-Speaking Caribbean and United States: History, Structure, Use, and Education. Lexington Books/Rowman \& Littlefield, Lanham, MD.

Wolfram Walt \& Erik R. Thomas (2002) The Development of African American English. Blackwell, Malden, MA.

\footnotetext{
* Thanks to Donald Winford, Nicholas Faraclas, and the editors for comments on earlier versions of this chapter. They are, however, not responsible for the current version's contents. Thanks also to Harriet Taber, who served as my research assistant during part of the preparation of this chapter.
} 